for any instant whatever. From the orbital velocity it is easy to deduce the length of the semi-axis major of the orbit, and the parallax is equal to the semi-axis major in seconds of arc, divided by the length of the same when expressed in astronomical units. The sum of the masses follows from the ordinary application of Kepler's third law. Dr. See lays special stress upon the importance of these investigations being taken up practically, as they will furnish us with "an absolute parallax exact to the highest degree," and will also enable us to apply a rigorous test of the universality of the law of gravitation. It is known already, from micrometrical measures, that Kepler's second law holds good for binary stars, and therefore that the force is central; but it remains to be shown that the principal star is in the focus of the real ellipse.

The Solar Parallax.--Among the various methods suggested as suitable for the determination of the solar parallax, that afforded by the parallactic inequality in the motion of the moon deservedly takes a high place. The reason is that in this particular term the parallax of the sun is multiplied by a coefficient which increases the quantity to be determined in the approximate ratio of I : I5, so that an error of a tenth of a second in the inequality would not produce an error of one-hundredth in the parallax sought. But in deriving the solar parallax it is necessarily assumed, that the relation hetween these quantities is accurately given by theory. Unfortunately there has been a discrepancy between the coefficients derived by Hansen and Delaunay, and the accepted explanation has not been the correct one. In order to ensure identity between Hansen and Delaunay it was necessary to suppose than an error existed in the highest term computed by Delaunay, and that the deviation of the remaining terms from the general character of the series did not exist. Recent work by Mr. Hill and Prof. Brown has, however, confirmed the accuracy of Delaunay's theory so far as this particular term is concerned, though it leaves a general doubt on the legitimacy of neglecting the higher terms in some of the series in other parts of the theory. Prof. Newcomb points out (Astronom. Tour. No. 356) that this more recent discussion of Messrs. Hill and Brown demands an increase on the theoretical value of Hansen, on which he had previously relied, of $\mathrm{o}^{\prime \prime} \cdot 3 \mathrm{O}$, and consequently a diminution in the solar parallax of $\mathrm{o}^{\prime \prime} \cdot \mathrm{O} 2 \mathrm{I}$ giving the corrected value of $\pi=8^{\prime \prime} \cdot 773$.

\section{THE EPPING FOREST MUSEUM AT CHINGFORD.}

THE opening of this museum, which we announced in our last week's issue as having been fixed for Saturday November 2, was in every respect an interesting ceremony, and marks a period in the history of the Essex Field Club, of which this active society may well feel proud. Two or three years after the foundation of the Club in I880, an informal meeting was held at the residence of Mr. E. N. Buxton, with a view to starting such a local collection, but the Conservators at that time had not long been in charge of the Forest, and they did not see their way to giving house-room for the museum in the old lodge known as "Queen Elizabeth's." The founders of the Club, however, have never lost sight of the desirability of having such a collection in the Forest district, and in February 1894 , a special meeting of local residents and others was convened, and a local sub-committee formed for the purpose of forwarding the scheme. A subscription list was opened, and a sufficient sum raised to warrant another application to the Conservators for the use of Queen Elizabeth's Lodge. This was granted, and the Banqueting Room, which from time immemorial has been unoccupied and devoid of fittings, has now undergone transformation into a museum, which was declared open to the public as a part of Saturday's proceedings. The arrangement of the collections, illustrating the natural history, geology, archæology, and topography of the Forest, has been entirely carried out by $\mathrm{Mr}$. William Cole, the Hon. Secretary of the Club, aided by his brothers and a few zealous workers who gave their co-operation, notably Messrs. W. Crouch, I. Chalkley Gould, A. Greenhill, and others. On Saturday afternoon a very representative gathering of scientific men took place at Chingford, to assist at the opening ceremony. The members and guests, comprising among the former Sir William Flower, Mr. Edward North Buxton, Profs. R. Meldola and G. S. Boulger, Mr. J. E. Harting, \&c., and among the latter a large number of the Epping
Forest Committee of the Corporation of London, were receiver by the President of the Club, Mr. David Howard, in a room adjoining the museum. After a few introductory remarks by the President, Sir William Flower addressed the meeting on the general subject of local museums and the advantages to be derived from their establishment. Mr. Deputy Halse, the Chairman of the Epping Forest Committee, then expressed, on behalf of the Corporation, the satisfaction which they all felt in being associated with the Essex Field Club in the movement, and declared that from Monday, the $4^{\text {th, the collections would }}$ be available for public inspection. The party then proceeded to view the museum, and great satisfaction was expressed at the large amount of material which had been brought together in a comparatively short time and with very modest financial means. Mr. Greenhill's collection of flint implements from the valley of the Lea, Mr. T. Hay Wilson's set of drift rock materials from the local glacial gravels, Mr. Crouch's shells of the Dengey Hundred, the cabinets of Forest flowering plants, fungi and insects, and the interesting set of relics found during the Club's explorations of the Forest earthworks, were all much admired. A pamphlet by $\mathrm{Mr}$. Chalkley Gould, being one of a proposed series of museum handbooks, was distributed at the meeting. The author in this pamphlet gives a description of the Romano-British station at Chigwell in illustration of the specimens which he has contributed to the museum. After the inspection the party assembled for tea at the Royal Forest Hotel, some eighty or ninety members and visitors being present. At a meeting of the Club, held after tea, the President moved a vote of thanks to Mr. William Cole and his coadjutors for the large amount of work which they had voluntarily done on behalf of the museum. This was warmly seconded by the Rev. A. F. Russell, the rector of Chingford, who is chairman of the local sub-committee. Mr. Cole having acknowledged the vote of thanks, Mr. A. Smith Woodward (of the British Museum) then gave a short address, in the course of which he pointed out the essential requirements that the museum should fulfil in order to be of real use, and commented most favourably upon the arrangement of the collections, their contents, and their mode of display. Sir William Flower expressed his concurrence with Mr. Woodward's remarks, and made some further observations and suggestions, especially dwelling upon the importance of taking steps to insure the permanence of the museum when those who had laboured so well for its foundation were no longer able to carry on the work. In the course of his remarks he paid a high tribute to the general work of the Essex Field Club, of which he had been an honorary member almost from the time of its foundation. Prof. Meldola, in proposing a vote of thanks to Mr. Deputy Halse, pointed out that the element of permanence to which Sir William Flower had alluded was most likely to accrue from their association with the Epping Forest Committee. This vote having been seconded by Mr. E. N. Buxton, and replied to by Mr. Halse, Mr. Harting made some remarks on the danger of encouraging promiscuous " collecting" by schoolboys, and the proceedings terminated. Favoured by an exceptionally brilliant autumnal afternoon, the meeting was a distinct success, and must have given great satisfaction to its promoters. The museum is necessarily small, but a good beginning has been made, and the time may be looked forward to when increased accommodation will be required. The feature which most strongly commends it to students of natural science, and lovers of the Forest generally, is the purely local character of the collections. No more appropriate use of Queen Elizabeth's Lodge could possibly have been made, and the Corporation of London have done wisely in allowing the Essex Field Club to found an institution which, however small and unpretentious, is, even as at present appointed, a distinct boon to all frequenters of the Epping Forest district.

\section{CONCENTRATION OF GOLD ORES.}

$W^{H E N}$ gold mining is a new industry in any country, the methods of extraction are often somewhat rough and ready. With great quantities of rich ore waiting for treatment or easily obtainable, the mill-man is usually intent on obtaining the greatest possible quantity of bullion in a short time, rather than on establishing a good system of reduction, which in the 1 " Report on the Loss of Gold in the Reduction of Auriferous Veinstone in Victoria." By Henry Rosales. (Issued by the Department of Mines, Melbourne, 1895.$)$ 